\section{Mulig behandling for «psykofysiske» diffuse plager?}

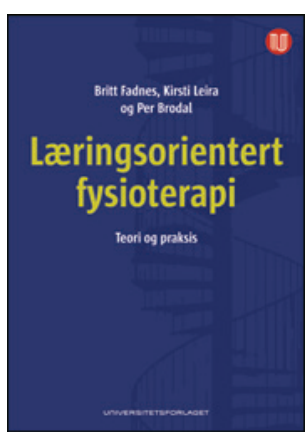

\author{
Britt Fadnes, Kirsti Leira, Per Brodal \\ Læringsorientert fysioterapi \\ Teori og praksis. 185 s, ill. Oslo: \\ Universitetsforlaget, 2013. Pris NOK 299 \\ ISBN 978-82-15-02118-8
}

Dette er ment som en lærebok for fysioterapeuter og fysioterapistudenter, men med mulig nytte for andre som arbeider med personer som sliter i hverdagen. Etter en fyldig innledning følger to deler. Del 1, Nevrovitenskapelig grunnlag for læringsorientert fysioterapi, er skrevet av Per Brodal. Den består av sju kapitler som omhandler hjernens nettverkorganisering, det nevrovitenskapelige grunnlaget for læring, balanse, smerte og kroppsrepresentasjon i hjernen. To kapitler omtaler kort tverrfaglig fagutvikling og hjernens arbeidsmåte - særlig i forhold til forventning og bevegelse. Kapitlene er interessant lesning og gir innsikt i hjernens organisering og arbeidsmåte.

Del 2 er skrevet av Fadnes og Leira, som er erfarne psykomotoriske fysioterapeuter som har arbeidet med utvikling av læringsorientert fysioterapi i årevis og har tidligere utgitt to bøker om temaet sammen med Brodal, Balansekoden i 2006 og Laringsnøkkelen i 2010. I tre kapitler beskrives grunnleggende erkjennelser for praksis, samt den metodikken som brukes i læringsorientert fysioterapi. Ti konkrete verktøy beskrives i en logisk rekkefølge, med startverktøyene tidlig. I siste kapittel presenteres ni pasienthistorier og forfatternes refleksjoner omkring effekt av behandlingen.

Som supplement til boken finnes en passordbeskyttet nettressurs. Her finner vi fire videoer med foredrag av Per Brodal som dekker det meste av stoffet i bokens del 1. Fanen merket «Kapittel 8» viser elleve videoer av barn i det første leveåret som utfører gradvis vanskeligere og mer sammensatte oppgaver. I fanen merket «Kapittel 9» vises de konkrete verktøyene i læringsorientert fysioterapi i 24 videoer.

Utgivelsen formidler tydelig at behandlingen er en prosess der læring i møtet mellom pasient og terapeut er et viktig element. Brodals del gir et godt fundament for å forstå kroppens representasjon i hjernen. Han beskriver hvordan ulike kortikale områder mottar sanseinformasjon som integreres i vår «kroppsoppfatning». Likedan beskrives subkortikale nettverk som samordner opplevelse av smerte og tretthet samt mulig påvirkning av disse sentrene, med tilhørende endring i opplevelse. Denne modellen knytter opplevelse av kroppen sammen med endret opplevelse av smerte, tretthet og psykiske symptomer. Brodals kapitler er evidenssbaserte med referanser.

Beskrivelsen av den læringsorienterte fysioterapien er erfaringsbasert fra Fadnes og Leiras virke som psykomotoriske fysioterapeuter. Dette gjelder også områder som svimmelhet og balanse, der det foreligger en stor mengde publisert vitenskapelig evidens som ikke refereres av forfatterne. Dette svekker boken. Allikevel er deres egne metoder klart beskrevet i kapittel 9, slik at personer som arbeider med svimmelhet og balanse, selv kan vurdere verktøyene.

Pasienthistoriene har det til felles at pasientene i varierende grad har psykiske symptomer. I tillegg beskrives ulike kroppslige plager og settinger pasientene lever i. Boken beskriver et fysisk fokus $\mathrm{i}$ behandlingen utført med de ulike verktøyene. I pasienthistoriene ser dette ut til å være effektivt også mot de psykiske symptomene. Noen vil nok mene at samtalebehandling kombinert med råd om fysisk aktivitet kunne gi samme effekter. Siden det ikke foreligger noe forskning på effekten av læringsorientert fysioterapi, kan vi ikke vite om metoden virker, og heller ikke hvilke elementer av den som er viktigst. Forankring gjennom forskning bør være en forutsetning når nye behandlingsmetoder skal innføres.

Loringsorientert fysioterapi gir et interessant innblikk i en metode som særlig retter seg mot en liten gruppe pasienter med sammensatte symptomer og opplevelse av manglende kontroll over egen kropp. Den kan imidlertid være vanskelig tilgjengelig om man ikke arbeider spesielt med slike problemstillinger.

Niels Gunnar Juel

Spesialist i fysikalsk medisin og rehabilitering, Oslo universitetssykehus

\section{Kortfattet og godt oppslagsverk i ortopedi}

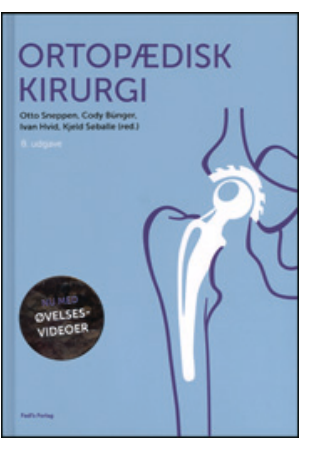

Otto Sneppen, Cody Bünger, Ivan Hvid et al, red. Ortopædisk kirurgi

8. utg. 708 s, ill. København: FADL's Forlag, 2014. Pris DKK 970

ISBN 978-87-7749-723-0

Målgruppen for den seneste utgaven av den danske læreboken Ortopcedisk kirurgi (1. utgave kom i 1986) er medisinstudenter og andre helsefagarbeidere med interesse for ortopedi. Boken skal også fungere som et oppslagsverk for dem som ønsker en kortfattet orientering om de aller fleste områder innen ortopedi.

Den er delt inn i fem hovedtemaer: diagnostisk metodikk, generelle behandlingsprinsipper, generell traumatologi, allmenn ortopedi og regional ortopedi, hvorav sistnevnte er det største og omhandler diagnostikk og behandling av topografisk avgrensede lidelser. Boken er skrevet på dansk, språket er generelt godt og lettlest. Den inneholder 945 figurer/illustrasjoner i tillegg til link til instruksjonsvideoer i ortopediske undersøkelsesteknikker.

Denne utgivelsen gir en god og kortfattet innføring i ortopedisk kirurgi. Den er oppdatert når det gjelder moderne behandlingsprinsipper og dekker alle de vesentlige områdene innen faget. Illustrasjonene er generelt gjennomtenkte og gode. Forfatterne formidler ortopedisk diagnostikk og behandling på en lettfattelig måte, og selv om den er skrevet på dansk, er den lett forståelig for norske lesere.

Den kan anbefales til medisinstudenter, allmennpraktikere, leger i tidlig fase av spesialistutdanningen i ortopedi og andre innen helsefag som arbeider med ortopediske problemstillinger og har behov for et kortfattet og godt oppslagsverk i moderne ortopedisk kirurgi.

Jonas Meling Fevang

Overlege, Ortopedisk avdeling

Haukeland universitetssykehus 